\title{
シグナル伝達系と薬剤感受性
}

西尾和人 1

要旨一一肺癌特異的に検出される変異型 EGFR は gain of function であり, 下流シグナルの活性化により, 発癌に寄与 すると推察される. EGFR に対する高い親和性がTKI に対する高い感受性をもたらすと推測されているが，詳細は不 明である. EGFR 変異の頻度は, アッセイ系, サンプルに大きく依存するが, EGFR 遺伝子変異と, EGFR-TKI の効果, とくに生存率との関連性は明らかでない. 正常型 EGFR を発現する肺癌症例における EGFR-TKI の効果を明らかにす ることも今後重要である.（肺癌. 2006;46:241-244）

索引用語 一一上皮増殖因子受容体, 遺伝子変異, プロテインキナーゼ B, マイトジェン活性化プロテインキナーゼ, 交差検定

\section{Signal Transduction and Drug Sensitivity}

\author{
Kazuto Nishio ${ }^{1}$
}

ABSTRACT - EGFR mutations observed in lung cancer are gain of function. These mutations activate downstream in the signaling pathway and are considered to play a role in carcinogenesis. It is likely that mutant EGFR shows high affinity to EGFR-targeted tyrosine kinase inhibitors (TKI) but the details remain unclear. Detection of EGFR mutations is largely dependent on the assay system and the quality of specimens. The relationship between EGFR mutation and survival of the patients treated with EGFR-TKI is also unclear. It is important to demonstrate the potential of EGFR-TKIs in patients with lung cancer with no mutational EGFR. (JJLC. 2006;46:241-244)

KEY WORDS — Epidermal growth factor receptor, Mutation, Protein kinase B, Mitogen-activated protein kinase, Cross validation

\section{はじめに}

ゲフィチニブ, エルロチニブなど EGFR 特異的チロシ ンキナーゼ阻害剤が非小細胞肺癌に対し使用され，その 有用性が示されつつある.肺癌における EGFR 遺伝子変 異と, ゲフィチニブに対する高い反応性が注目され， EGFR 遺伝子をめぐる様々な研究が急速に進展した。本 稿では EGFR を標的とするチロシンキナーゼ阻害郕の 動向を整理したい.

\section{1. 変異型 EGFR の機能}

EGFR の遺伝子変異の機能についての基礎的検討によ
り得られた知見を Table 1 にまとめた. エクソン 18 から エクソン 21 を中心に報告された遺伝子変異は 30 程度に のぼる.ほとんどの EGFR の遺伝子変異の機能としては “gain of function”すなわち活性型変異であると考えられ ている.すなわち, EGFR の遺伝子の変異が扔こることに より, 下流のシグナル伝達が充進し, 発癌過程が進行す ると考えられる.

EGFR はリガンド TGF- $\alpha$ や EGF などが細胞外に結 合することにより，インターナリゼーションが抗こり， アダプター蛋白質と複合体を形成し，活性化する．変異 型 EGFR では, インターナリゼーションの過程が野生型 EGFR に比べて元進していると考えられている. また, そ

tute, Japan.

Reprints: Kazuto Nishio, 11F Shien-Lab, National Cancer Center Hospital, 5-1-1 Tsukiji, Chuo-ku, Tokyo 104-0045, Japan.

(C) 2006 The Japan Lung Cancer Society 
Table 1. Recent Progress in Biological Evidence Regarding Mutant EGFR

Gain of function (both of deletional mutations and deletional
mutations)
Prolonged half life - resistance to proteolysis
Oncogenic?
Variation in the effect to cellular sensitivity
Increased affinity to EGFR-TKI?
Identification of functional phosphorylation sites
Activation of PI3K and AKT
Increased dimerization (heterodimerization?)
No standardized detection assay for clinical samples
Acquired mutation in exon 20

の過程で再利用 (リサイクル) か分解されるが, 分解の 過程が変異型 EGFR では低下しているとの報告もある. その分解の過程に関与する $\mathrm{c}-\mathrm{Cbl}$ などの役割についても 検討がなされている.1

EGFRのさらに下流のシグナルとしては, 従来から, MAP キナーゼの経路, PI3 キナーゼ一AKT の経路が重 要であると考えられてきたが, 変異型 EGFRにおいては $\mathrm{AKT}$ 経路の役割がより重要になっていると示唆される 報告が多い. しかし活性型 EGFR の下流は MAP キナー ゼの経路, PI3 キナーゼーAKT の経路の両者が活性化さ れており, TKI に対する反応性のみ低下するとの報告も みられる. ${ }^{2}$ 一般に gain of functionをともなう遺伝子変 異は ongogenenic であり, 癌細胞の悪性度が増し, その 増殖は艺進する. 一方, 各種の変異型 EGFR の遺伝子導 入細胞においては, 明らかな増殖速度の艺進が認められ るわけではない. また, 変異型 EGFR を発現する肺癌症 例では変異を有しない肺癌に比べて, 予後が悪くなると いう明確なデータは示されていない. むしろ，限定され た病期において，予後が良好ではないかという議論もあ る.いずれにしろ発癌過程における変異型 EGFR の機能 はまだ必ずしも明らかではない. 以上のように gain of function に基づく変異型 EGFRの発癌における役割は 示唆されているが, その証明はなされていない.

\section{2. 変異型 EGFR と EGFR-TKI に対する感受性・耐 性}

変異型 EGFR の機能の生物学的機能について考察し たが, 注目されている点は変異型 EGFR を有する細胞に おいて EGFR-TKI に対し高い感受性を示すことである. それらは, 基礎的には変異型 EGFR 遺伝子導入実験で,
EGFR-TKI に対する高感受性の獲得が示されている. ${ }^{3}$ また, 臨床サンプルで報告された各種変異型 EGFR の遺 伝子導入実験によって, 種々の EGFR の変異型により EGFR-TKI に対する感受性が異なることが示唆されて いる. すなわち, EGFR 遺伝子変異陽性細胞であっても, 変異の部位により感受性獲得の程度が異なり, 場合に よっては, 変異を有していても感受性が変わらない場合 もあるということが示唆される.さらに，エクソン 20 上の 790 番目の変異の場合は, この変異型遺伝子の導入 により EGFR-TKI に対する耐性が獲得されることが報 告された. 4

これらの EGFR遺伝子変異をもつ細胞において EGFR-TKI に対する高い感受性獲得の機序は, 細胞レベ ルでは, EGFR-TKI によるEGFR のリン酸化阻害が低濃 度でおこること，またコンピュータを用いたドッキング シミュレーションから, 変異型 EGFRの TKI に対する 高い親和性が推測されている. しかし実際の EGFR 蛋白 質での親和性を測定してみると, 理屈どおりにはいかな いことも報告される. ${ }^{5}$ ある測定系では, すなわち, 野生 型 EGFR と変異型 EGFR 蛋白質と TKI との結合親和性 は変わらない, あるいは, その差が大きな感受性の違い を説明できるほど大きくない結果が得られる。これらは 測定系の問題なのか, 本来の変異型 EGFR の特徴なのか 不明であるが, 変異型 EGFR を発現する細胞における感 受性獲得の機序についてはなお慎重に検討する必要があ る.

\section{3. 感受性予測因子としての変異型 EGFR}

多くの施設の臨床サンプルの EGFR 遺伝子変異の検 討により, EGFR の遺伝子変異の頻度は約 10～30\% であ り, 東洋人にその頻度が高く, 大腸癌, 食道癌等に若干 の EGFR 遺伝子変異の報告がみられるものの, ほぼ肺癌 に集中して EGFR 遺伝子変異が認められる.

EGFR は病理学的には, ごく早期の肺癌から認められ ることも示唆されるが, 臨床的な予後との関連性では, 少なくとも早期 (IB 期まで) 症例における EGFR 変異と 予後との関連性は否定的であると考えられている. 組織 別には, 若干大細胞癌, 扁平上皮癌で認められたという 報告もあるが，ほほ肺腺癌特異的である，BAC あるいは BAC feature と EGFR 遺伝子変異との関連性も示唆さ れており,エクソン 19 の欠失型変異が多いと推測してい る研究グループもある.

EGFR 遺伝子変異とゲフィチニブに対する奏功率との 関連性では, EGFR 変異を有する肺癌患者において高い 奏功率が示されている。 一方, TTP や OS の指標として は, IDEAL, INTACT にエントリーされた症例では EGFR 変異陽性群と陰性群で差がないこと, タルセバ投 
Table 2. Cross Validation of EGFR Mutation

\begin{tabular}{|c|c|c|c|c|c|c|c|c|}
\hline \multirow[b]{3}{*}{ Samle } & \multicolumn{8}{|c|}{ EGFR } \\
\hline & \multicolumn{2}{|c|}{ Exon 18} & \multicolumn{2}{|c|}{ Exon 19} & \multicolumn{2}{|c|}{ Exon 20} & \multicolumn{2}{|c|}{ Exon 21} \\
\hline & DFCI & VUMC & DFCI & VUMC & DFCI & VUMC & DFCI & VUMC \\
\hline \multicolumn{9}{|c|}{ DanaFarber } \\
\hline 1 & WT & $\mathrm{NE}$ & del746_750 & WT & WT & SNP787 & WT & WT \\
\hline 2 & WT & $\mathrm{NE}$ & WT & WT & SNP 787 & SNP787 & SNP836 & SNP836 \\
\hline 3 & WT & WT & WT & WT & WT & NE & WT & WT \\
\hline 4 & WT & WT & WT & WT & WT & WT & WT & WT \\
\hline 5 & WT & WT & WT & WT & WT & WT & WT & WT \\
\hline 6 & WT & WT & WT & WT & WT & WT & WT & WT \\
\hline 7 & WT & WT & E740, del747_749, A760F & E749_T751 Del * & WT & WT & WT & WT \\
\hline 8 & WT & WT & del746_750 & E746_T750 Del & SNP 787 & SNP787 & WT & WT \\
\hline 9 & WT & WT & WT & WT & WT & SNP787 & WT & WT \\
\hline \multicolumn{9}{|l|}{ VUMC } \\
\hline 1 & ND & WT & deletion & Del Ex19? & ND & WT & WT & WT \\
\hline 2 & WT & WT & deletion & Del Ex19? & WT & SNP787 & WT & WT \\
\hline 3 & ND & WT & low PCR & WT & ND & WT & low PCR & WT \\
\hline 4 & ND & WT & low PCR & WT & $\mathrm{ND}$ & WT & low PCR & WT \\
\hline 5 & ND & WT & WT & WT & ND & SNP787 & WT & WT \\
\hline 6 & $* * *$ & WT & $* * *$ & Del Ex19? & $* * *$ & SNP787 & $* * *$ & WT \\
\hline 7 & ND & WT & low PCR & Del Ex19? & ND & SNP787 & low PCR & WT \\
\hline 8 & ND & WT & WT & Del Ex19? & ND & SNP787 & WT & WT \\
\hline 9 & WT & WT & deletion & Del746_750 & WT & SNP787 & $?$ & WT \\
\hline 10 & ND & WT & WT & WT & ND & SNP787 & WT & WT \\
\hline 11 & & WT & low PCR & Del Ex19? & & SNP787 & low PCR & WT \\
\hline 12 & WT & WT & WT & WT & ND & WT & ? & WT \\
\hline 13 & $*$ & WT & $*$ & Del Ex19? & $*$ & WT & $*$ & WT \\
\hline
\end{tabular}

* difficult to determine where deletion starts exactly since mutation peaks are very small

$\mathrm{NE}=$ not available because of low product

$* * *=$ We got an unusual pattern in all exons for this sample. Not clear why.

? possible mutation = await secondary confirmation

Giaccone IASLC ’05

与群とプラセボを比較した BR. 21 研究 6 においても, 同 様の結果である. 一方, コロラド大学らのグループでは, EGFR 変異の有無では説明できなかった症例で，FISH 陽性群と陰性群では治療効果に差があると報告してい る.これらの予想に反する結果については，様々な論議 がなされている. EGFR 遺伝子変異の解析を実施できた 症例が限られている，解析の方法, 感度, 精度に差があ る等である，後者について，次項で説明する.

\section{EGFR 遺伝子変異解析の方法, 感度, 精度}

従来の EGFR 遺伝子解析は主に手術切除標本を用い て行われてきた. またその奏功率との解析はレトロスペ クティブに行われてきた.

現在行われている臨床試験においては, EGFR 遺伝子 変異の有無によって選択される患者を対象とする前向き 試験も試みられている。，その場合，TBLB などによる生 検組織を解析対象とする場合が多く, 組織量が少ない, 正常細胞の混入など EGFR 遺伝子変異の検出はより困
難となっている. EGFRの変異の検出法はダイレクト シークエンスが主流であったが, その検出感度はあまり 高くなく, サンプル中に正常に比して癌細胞の割合が少 ない場合には, 変異遺伝子の検出は困難になる。 そこで, 腫瘍をダイレクトシークエンスあるいはマクロシークエ ンス（肉眼的に腫瘍部分だけを選択する方法）によりエ ンリッチメントすることによりその感度を上げることが 比較的多く用いられるようになっている. PCR-SSCP 法 による点突然変異の検出も行われている.

また, EGFR 遺伝子変異検出系については, 30 以上の 特許, バイオカンパニー, ベンチャーが参画しており, どのアッセイ系を使用するか迷うところになっている. 一方, 臨床的には, 高感度, 特異的で, 迅速で, 低コス トなものが望まれるであろう。また，国際的にも同一基 準での EGFR 変異測定が望まれる.

前述の BR21 研究においての 1 つの論議は, 変異を認 めた症例のうち, エクンン 19 の欠失, エクソン 21 の点 突然変異 (L858R) をあわせても50\%にみたず, その他 
が $53 \%$ にのぼる. 従来の報告では, これら 2 つの変異が EGFR 遺伝子変異の $80 \%$ 程度をしめることから, 測定方 法の違いなのか, 検査サンプルのバイアスなのか, さら には, これら一部の症例で, 臨床試験全体を語ってよい のかということが議論されている. 2005 年世界肺癌会議 において, Free 大学の Giaccone 教授は, Table 2 のよう な cross-validation データを発表した.すなわちダナ ファーバ癌研究所とFree 大学で同一サンプルを別々に EGFR 遺伝子の検出を行い検討した結果である．結果が 異なるケースもみられた。このような cross over 検証研 究と, それぞれのアッセイ系の感度特異性の検定は, 今 後の研究で必要と考えられる.

\section{5. 他の因子}

前述のように, 本年度のASCO, AACRにおいて EGFR 遺伝子変異と TTP, OS の関連性が示されなかっ たデータが相次いで発表されたことにより，もはや EGFR 遺伝子変異の測定をする必要がないという議論も なされている. 一方, EGFR-TKI の有効性を示すため, 選択された患者群での臨床試験の必要性も検討されてい る.一方, わが国においては, $\mathrm{SD}, \mathrm{NC}$ 症例における EGFR-TKI の臨床的有用性を示すことも重要である. そ ういった意味で, EGFR 遺伝子変異以外, あるいは EGFR 遺伝子変異とは独立した, 治療予後マーカーが求められ ている. 我々が見出した新しい効果予測マーカーはその 範疇にあるが, 現在慎重に検証研究をすすめている.

\section{6. 今後の展開}

ゲフィチニブとエルロチニブはどう違うかについて
は, 臨床的に興味ある課題であると思われる.これに対 する回答として基礎的には, (1) EGFR 変異型に対する作 用の違い. (2) 野生型 EGFRに対する作用の違い,

（3）EGFR-TKI 耐性細胞における作用の違い, (4) その 他にわけて論じることが可能である.

感受性予測因子, 肺障害予測マーカーなどについては, 今後も検討されていく必要があるが, 臨床試験における 検証研究がますます重要と考えられる.

\section{REFERENCES}

1. de Melker AA, van der Horst G, Borst J. Ubiquitin ligase activity of c-Cbl guides the epidermal growth factor receptor into clathrin-coated pits by two distinct modes of Eps15 recruitment. J Biol Chem. 2004;279:55465-55473.

2. Sakai K, Fukumoto H, Arao T, et al. Dimerization and the signal transduction pathway of a small in-frame deletion in the epidermal growth factor receptor. FASEB. (in press).

3. Arao T, Fukumoto H, Takeda M, et al. Small in-frame deletion in the epidermal growth factor receptor as a target for ZD6474. Cancer Res. 2004;64:9101-9104.

4. Kobayashi S, Boggon TJ, Dayaram T, et al. EGFR mutation and resistance of non-small-cell lung cancer to gefitinib. N Engl J Med. 2005;352:786-792.

5. Fabian MA, Biggs WH, 3rd, Treiber DK, et al. A small molecule-kinase interaction map for clinical kinase inhibitors. Nat Biotechnol. 2005;23:329-336.

6. Tsao MS, Sakurada A, Cutz JC, et al. Erlotinib in lung cancer - molecular and clinical predictors of outcome. $N$ Engl J Med. 2005;353:133-144. 